\title{
Determinants of Sustainable Supply Chain: an Analysis of Mensuration Models of Pressures and Socio- Environmental Practices
}

\author{
Etienne Cardoso Abdala \\ etienne@fagen.ufu.br \\ Universidade Federal de Uberlândia \\ Jose Carlos Barbieri \\ jose.barbieri@fgv.br \\ Fundação Getúlio Vargas - Escola de Administração de Empresas de São Paulo
}

ABSTRACT: Sustainability became an important topic concerning the management of the supply chain. Therefore, this study aims to understand the determinant factors of the pressures, and environmental practices on the management of the sustainable supply chain, from the development of two measurement models: 1) pressures and 2) socio-environmental practices accomplished by the companies. The methodology was based on a survey application in processing industries of Minas Gerais state. Data analysis was performed using descriptive statistics, exploratory and confirmatory factor analysis.

Keywords: Sustainability; Sustainable Supply Chain Management, Pressures; Socio environmental Practices 


\section{INTRODUCTION}

Sustainability genesis refers to the conditions and resources that the organizations must gather in terms of social and environmental aspects, in order to attend the demand of present market and society without harming the supply future needs. This concept is one of the most used on the academic environment to define what is comprehended by sustainable development. Carter and Rogers (2008) report that after this consensual definition about sustainable development the term sustainability started to appear in the literature of subjects as management and operations, and the companies began to adopt the term on the organizational routine. The sustainability also began to be comprehended as a possible advantage source and survival at the market, relating itself, so, to the strategic issues and organizational performance, according to Porter and Van Der Linde (1995), Cruz, Pedroso and Martinet (2007); Neutzling, Libera and Pedrozo (2011).

In many cases companies modify their environmental performance, adapting themselves to a context in favor of the sustainability in response of the origin pressures as environment groups, consumers, government, nongovernmental organization, among others. Angell and Klassen (1999) assert that as a result of the pressures suffered, several companies began to develop approaches to manage the environmental issues and, for that reason, the managers of the operation area started to assume responsibilities about developing and implementation of environmental systems of operation. Thus, partnership relations with suppliers, transport companies and logistics, and the relation with the final consumers increase or attenuate the environmental risks related to the production.

The importance of developing sustainable actions on the entrepreneurial environment can be explained, most of the time, by reason of the regulatory exigencies concerning the responsible use of environmental and human resources; and also for the improvement of the economical performance of the organizations, suggesting that the focus on sustainability may mean an additional advantage of the firm and, consequently, a rise of competitiveness of the company at the market where it works. For Sarkis, (2001) the production plays a central and critique function in the organizations role in terms of ecocentrism and eco-efficiency, what is considered the next 'industrial revolution', since all approaches directed to ecological issues reveal the necessity of consider the environment on the strategies and op- erations of organization.

Considering that sustainable actions related to operational area have become valuable to reach competitiveness, these issues have become fundamental in terms of the management of a supply chain. The addition of sustainability on the supply chain management resulted in what is denominated in the academic and management fields as Sustainable Supply Chain Management. The pressures exerted by the several stakeholders on the organizations are determinants for that these select their social environmental practices in the scope of the supply chain management and the study of the pressures and the sustainable actions are essential to the better comprehension of construction, of the operations and the maintenance of the supply chains.

In this sense, the study described in this article intends to identify, from an empiric research conducted in companies and based on the theoretical background about the topic, two distinct models: a model that comprehends the indicatives of the pressures that the organizations are subject to and another that presents the possible socio environmental practices conducted on the supply chain management. In order to accomplish the research objectives a multivariate data analysis was performed using data collected in 131 industries of Minas Gerais state. For the data processing was adopted an exploratory factor analysis and confirmatory, which made possible the validation of the models proposed on the research.

\section{LITERATURE REVIEW}

\subsection{Sustainable thinking in the operational environment}

The definition of sustainability highlighted by the World Commission on Environment and Development and divulged by report of Brundtland conference is widely commented in several studies on which the theme is based, like Gladwin, Kennely e Krause (1995); Nordahaus (1998); Angell e Klassen (1999); Bansal (2005); Glavic e Lukman (2007); Seuring e Muller (2007) and refers to the proper use of the resources in the present in a way that does not affect the future generations in terms of social and environmental, without though, minimize the economical development.

The concept of sustainable development emerged as a reaction to the theoretical approaches about the limits to growth, but not as a result of a new proposal nova for these approaches and emphasizing the regulations as a way to stop environmental degrada- 
tion. The comprehension of the concept and of the elements that involve the sustainable development is diffuse due to the enormous range of Sciences and knowledge that contribute to the definition and to the study.

Among challenges and questioning, it is suggested that the economic development of the countries and organizations toward sustainability became an essential element in the formulation of strategies and performance of organizational activities. Recent researches and the growth of knowledge about sustainable development has increased interest in understanding the terminology of sustainability, this term was gaining space during all last decade. Examples of what could represent sustainability appear on terms cleaner production, prevention e pollution control, minimization of resource use, ecodesign among others (GLAVI E LUKMAN, 2007).

The sustainable production infers that all the phases of the chain's product are seen conforming the requirement necessities, since the design of the product until the materials recuperation. Therefore, in order to reach the sustainable production to all chain, each activity must be sustainable, which means that the three main activities of a chain must be optimized: product design, transformation and recuperation (RON, 1998). O'Brien (1999) defines sustainable production as the development of ability on manufacture of the industries in supporting the society's needs not only to promote welfare and prosperity, but to make it in a way to support a sustainable economic development.

It is evident, so, that theorganizations should lead strategic thinking to the relation that they establish with other institutions that contribute for your productive process, as in case of suppliers, for example. Sharma e Henriques (2005) conclude that due pressure from different groups of stakeholders, many organizations recognize the importance of their suppliers develop responsible environmental and social actions. As reported by (Vachon e Mao, 2008) all industries will be challenged to re-organize their supply chains while preserving the environment and respecting all local communities where they are inserted.

\subsection{Sustainable Supply Chain Management}

When considering that sustainability has become one of the competitive priorities of firms, and that the stimulus for environmental management is vital for the sustainable development to occur, the concept of supply chains no longer presents a traditional set-up and is transformed into a more 'extended' version. The concept of management of a sustainable supply chain is comprehended by the management of the flow of materials, information and capital, as well as the cooperation between companies along the chain, as they reach their objectives in the three dimensions of sustainability (economic, social and environmental), starting with the needs of the stakeholders and final consumers. (SEURING and MULLER, 2008b; LINTON, KLASSEN and JAYARAMAN, 2007). Seuring and Muller (2008); Koplin, Seuring and Mesterharm (2007); Kleindorfer, Singhal and Van Wassenhove (2005); Pagell and Wu (2009); Linton, Klassen and Jayaraman (2007) and Carter and Rogers (2008) present the contextualization, main characteristics and theme evolution in their studies.

In order to understand the constituent elements of the sustainable supply chains and the relations established between them, it is necessary to involve the constituent elements of the supply chain management and the aspects related to sustainability, specifically the three dimensions of sustainability, known as Tripple Bottom Line (TBL), defended by Elkington (2001): economic, social and environmental. The consideration of these three pillars in the existing practices of Supply Chain Management leads us to Sustainable Supply Chain Management, including the inter-organizational dimension as well as the perspective of added value and social environmental issues.

It is important to highlight that previously the configuration of an own theory about sustainable supply chain management (SSCM) that inserts all dimensions of TBL, the management of the traditional supply chain has directed, firstly, their actions only to an environmental perspective, beyond the fundamental economic goals. The influence of an environmental management in a supply chain resulted in the definition of the approach known as Green Supply Chain Management (GSCM) that had its origins the environmental operations systems. According to Minatti, Alberton and Marinho (2011), the article of Srivastava (2007), one of the most quoted when talking about GSCM, reports a fragmentation of the Green Supply Chin Management, showing that the theme needs more development.

The big difference between GSCM and SSCM is the fact that the management of the sustainable supply chain incorporates the social aspects in their practices and actions. Carter and Rogers (2008) define SSCM as a strategic integrated network in the way it reaches its social, environmental and economic ob- 
jectives in a transparent business coordination system and inter-organizational processes, for the improvement of the long-term economic performance of a focal organization and its supply chain.

Nevertheless, it is opportune to question to what extend the supply chains can deal with the three dimensions of the tripple bottom line on a proper way to produce positive economical results, socials and environmental, in other words, the reflection about the level of sustainability existent in the chain. Pagell and $\mathrm{Wu}(2009)$ believe that for the supply chain be really sustainable, the involved organizations should not commit any act that reaches the resources and natural or social systems while producing profitable long-term results, and could from the customers disposition, provide continuity of realization of business unlimitedly.

The discussion about levels of sustainability and measure of how much a supply can be sustainable and provide good results in the TBL dimensions has been occurring since the definition of the SSCM as one of the great approaches of an organization in the área of operations. Questions and queries have been pointed out not only by Pagell and Wu (2009), but also previously by Kleind orfer, Singhal and Van Wassenhove (2005), who point out the question of the synergy between profits and sustainable practices as the center of debate on the theme, especially because society often seems to be uninterested or indifferent to economic and political arguments.

Some relevant models in terms of sustainable supply chain management are the ones presented by: Linton, Klassen and Jayaraman (2007); Seuring and Muller (2008b); Carter and Rogers (2008); Pagell and Wu (2009). Antecedents of SSCM were discussed by Kleindorfer, Singhal e Van Wassenhove (2005) concerning elaboration of an aspects review, on the sustainability context, related to other elements as environmental management, supply chain and a wide perspective of thinking about TBL, integrating profits, people and planet on culture, strategy and organizations operations. This way the authors consider sustainability as a key element for the supply chains, comprehended as business models capable of converge competitive advantages and social needs in an only approach.

\subsubsection{Determinants of the Sustainable Supply Chain: Models of Pressures and Socio-environmental practices}

In many cases, companies modify their environmental performance in response to origin pressures as environmental groups, consumers, and regulations, among others. However, according to (Hall, 2000) not all firms are exposed to the same type of pressure and the same intensity. In general, firms that have high financial performance are more regularly under pressure of improvements concerning environmental performance while many suppliers need incentive for that. In contrast to other innovation ways, companies that do not suffer so much pressure may hesitate regarding investments accomplishment about environmental innovation, because they do not need to seek improvements for their financial performance.

One of the pioneer studies in the field of the definition of determinants was that of Henriques e Sadorsky (1996) who sought to identify the formulation of environmental plans was being influenced by pressure from clients, shareholders, society and governmental regulations. The authors believed that environmental regulations was one of the factors that most affected the decision-making process of an organization, and this pressure from the government was understood as necessary due to the environmental costs of a productive process, like pollution and other toxic residues.

Many authors highlight the external pressures and the regulation environmental issues that take the organizations to adopt socio-environmental practices characterized as sustainable in their routines. Sarkis (2001), Preuss (2001), Zhu, Sarkis and Geng (2005), Welford and Frost (2006) and Carter and Jennings (2002), Sharma and Henriques (2005) and Rao (2005), Seuring and Muller (2008a), Seuring and Muller (2008b) emphasize that the pressures exerted by the government, consumer market and by the governmental organizations related to sustainable actions to be practiced by the organizations in a general way.

Zhu and Sarkis (2004), Zhu, Sarkis and Geng (2005), Zhu and Sarkis (2007) and Zhu, Sarkis and Lai (2008) studied the regulatory practices and the consumer market about the organizations concerning environmental practices in supply chain management, considering, for that, the Chinese context. In China the pressures for the pollution control, among other harmful that affects the environmental preservation has become more and more expressive and the habits of the people and organizations damage significantly the quality of life of the population bringing high level of political dissatisfaction, what reinforces the pressure by measures capable of regularize the use of polluter components.

Beyond governmental pressures, institutional and of regulation is highlighted as possible inductors and 
conductors of sustainable actions, here comprehended as socio-environmental, pressures of the consumers and other stakeholders, as suppliers, syndicates and non-governmental organizations. Henriques and Sadorsky (1996); Rao (2005); Handfield et al. (1997); Sarkis (2001); Sarkis (2003); Sharma and Henriques (2005); Srivastava (2007); Seuring and Muller (2008a); Seuring and Muller (2008b) and Mann et al. (2010) highlight that the pressure of stakeholders, especially the clients and other institutions that establish direct relations with a company in a supply chain, should be considered antecedents for the insertion of sustainable practices. Delmas and Toffel (2004); Hsu et al. (2013) affirm that the pressures of the clients and suppliers has demanded that many organizations in Malaysia adopt correct environmental practices.

However, not only the external factors should be considered responsible for assume a conductive role concerning socio-environmental practices in companies, but the internal variables, presents in organizations, also should be inserted and evaluated inside this induction process. Some internal questions of the companies like costs, high administration involvement, values and initiatives organizational, reputation and brand image, relation with suppliers, strategic orientation, and development of competitiveness advantages are presented as inductors of sustainable practices. (ZSIDISIN and SIFERD,
2001; CARTER and ROGERS, 2008; ROUTROY, 2009; MANN et al., 2010, GOLD, SEURING and BESKE, 2010; AGERON et al., 2011; PAULRAJ, 2011; CLARK, 2012). So, the theoretical model of the pressures presents the following constructs: government pressures, client's pressures, suppliers' pressures, and internal aspects of the organization.

Socio-environmental practices defined on the model of practices are characterized by the activities related to environmental management in supply chain and social actions accomplished by organizations. An operational approach in green supply chain management includes activities like recycling, reutilization and materials substitution, and it results in a confluence of elements of corporate environmental management and supply chain management (ZHU and SARKIS, 2004). According to Zhu, Sarkis e Geng (2005) the practices of 'green' supply chain management include eco-efficiency, clean production and environment management system. Eltayeb and Zailani (2009) divide environmental initiatives in a green supply chain into three aspects: eco-design, or design for the environment, green purchases and reverse logistics.

The references presentation in what are based the main ideas inserted on the construction of models are found in table one, that treats the references summary used as bases of the theoretical model of 'Pressures':

\section{Table 1: References of the Theoretical Model of Pressures}

\section{Summary Table of References of the Theoretical Model of Pressures}

\begin{tabular}{|c|c|c|}
\hline \multicolumn{3}{|c|}{ Summary Table of References of the Theoretical Model of Pressures } \\
\hline Constructs/Variables & References Included on Model & Bibliographic References Researched \\
\hline Government Pressure & $\begin{array}{l}\text { Sarkis (2001), Preuss (2001), Carter and } \\
\text { Jennings (2002), Zhu and Sarkis (2004), } \\
\text { Sharma and Henriques (2005), Zhu, Sar- } \\
\text { kis and Geng (2005), Welford and Frost } \\
\text { (2006), Zhu and Sarkis (2007), Seuring } \\
\text { and Muller (2008b), and Zhu, Sarkis and } \\
\text { Lai (2008); Routroy (2009); Mann et al. } \\
\text { (2010); Clark (2012) }\end{array}$ & \multirow{4}{*}{$\begin{array}{l}\text { (1995); Handfield et al. (1997); Sarkis } \\
\text { (2001); Preuss (2001); Roberts (2003); } \\
\text { Seuring (2004); Zhu et al. (2005); Pre- } \\
\text { uss (2005); Rao (2005); Sharma and } \\
\text { Henriques (2005); Welford and Frost } \\
\text { (2006); Zhu and Sarkis (2007); Seuring } \\
\text { and Muller (2008a), Seuring and Muller } \\
\text { (2008b); Zhu, Sarkis and Lai (2008); } \\
\text { Routroy (2009); Mann et al. (2010); } \\
\text { Gold, Seuring and Beske (2010), Carval- } \\
\text { ho (2011); Berardi (2012); Clark (2012). }\end{array}$} \\
\hline Customer Pressure & \multirow{2}{*}{$\begin{array}{l}\text { Henriques and Sadorsky (1996), Hand- } \\
\text { field et al. (1997), Sarkis (2001), Sarkis } \\
\text { (2003), Delmas and Toffel (2004); Sriv- } \\
\text { astava (2007), Mann et al. (2010) and } \\
\text { Seuring and Muller (2008b) }\end{array}$} & \\
\hline $\begin{array}{l}\text { Pressure from other Stakeholders - } \\
\text { Suppliers }\end{array}$ & & \\
\hline Internal Aspects & $\begin{array}{l}\text { Zsidisin e Siferd (2001); Carter e Rog- } \\
\text { ers (2008); Routroy (2009); Mann Et Al. } \\
\text { (2010), Gold, Seuring e Beske (2010); } \\
\text { Ageron et al. (2011); Paulraj (2011); } \\
\text { Clark (2012) }\end{array}$ & \\
\hline
\end{tabular}


Table 2: References of the Theoretical Model of Practices

\begin{tabular}{|c|c|c|}
\hline \multicolumn{3}{|c|}{ Summary Table of References of the Theoretical Model of Practices } \\
\hline Constructs/Variables & References Included on Model & Bibliographic References Researched \\
\hline $\begin{array}{l}\text { Socio-environmental prac- } \\
\text { tices }\end{array}$ & & \\
\hline $\begin{array}{l}\text { - Activities in Environmen- } \\
\text { tal Management } \\
\text { - External Environmental } \\
\text { practices } \\
\text { - Development of Environ- } \\
\text { mentally friendly products }\end{array}$ & $\begin{array}{l}\text { Zhu e Sarkis (2004); Pullman, Ma- } \\
\text { loni and Carter (2009); Tate, Ellram } \\
\text { and Kirchoff (2010); Ageron et } \\
\text { al. (2011); Paulraj (2011); Hollos, } \\
\text { Blome and Foerstl (2011); Clark } \\
\text { (2012) }\end{array}$ & $\begin{array}{l}\text { Handfield et al. (1997); Min and Galle } \\
\text { (2001); Zhu and Sarkis (2004); Vachon } \\
\text { and Klassen (2006); Carter and Rog- } \\
\text { ers (2008); Krause, Vachon and Klassen } \\
\text { (2009); Pullman, Maloni and Carter. } \\
\text { (2009); Eltayeb and Zailani (2009); } \\
\text { Pagell and Wu (2009); Tate, Ellram and } \\
\text { Kirchoff (2010); Paulraj (2011); Hollos, } \\
\text { Blome and Foerstl (2011); Ageron et al. } \\
\text { (2011); Clark (2012) }\end{array}$ \\
\hline - Social Practices & & \\
\hline
\end{tabular}

Source: Own elaboration

The representative figures of the theoretical models proposed of former constructs of the pressures and socio-environmental practices are going to be exposed on the presentation research results, after the description of methodological procedures.

\section{METHODOLOGICAL PROCEDURES}

The main purpose of this research was to identify if factors that characterize such as, government pressures, customers, suppliers and organizational internal aspects and activities adopted as environmental practices in companies. The identification of these practices also works as a general mote for the research developed in companies, located at Minas Gerais state, which was selected because of two reasons: first because the state is part of the Southeast region, the most industrialized of the country (the state has strong industrial activity, steel industry, metallurgy and chemical), and second because of the easy access to the industry database of the Federação das Indústrias de Minas Gerais (FIEMG).

In order to identify relations between the variables, this research is considered descriptive, according to Hair Jr. et al. (2005), it is characterized as a structured study and elaborated to evaluate the characteristics defined in research question, which involves confirmation or not of hypotheses derivative from theory.
The instrument adopted in this research was an electronic survey, which was performed through the distribution of a questionnaire via e-mail, to the addresses, previously selected by the database available on CD by Cadastro das Indústrias de Minas Gerais da FIEMG. A technique of sample survey is the most common type and indicated for the accomplishment of this kind of research. This survey aims to make possible quantitative descriptions of a sample, adopting some defined instrument for data collecting.

The population considered for the research were the industries registered on FIEMG. Approximately 1000 industries of multiple sectors of Minas Gerais state were contacted; the return rate was $13 \%$ of the sample total. The total of valid answers was 131 observations, considering questionnaires completely filled.

The questionnaire adopted was divided into two parts for the mensuration of two theoretical models that were proposed. On the first part 19 (nineteen) indicators were used for the evaluation of the adoption of sustainable practices. The scale used was a likert type of five points ranging from 'non influenced' (1) to 'highly influenced' (5). The scale used was based on any other previously published, but adaptations were done on questions utilized by 
Henriques and Sadorsky (1996); Ageron et al. (2011); Paulraj (2011); Hollos, Blome and Foerstl (2011) on their researches.

In the second part of the questionnaires for the evaluation of the model of practices and elaboration of indicators that measure the three environmental variables was completely based on the adaptation of the scale developed by Zhu e Sarkis (2004). The elaboration of indicators of variables 'Social Practices' was based on Ageron et al. (2011); Paulraj (2011); Hollos, Blome e Foerstl (2011), but it was adapted to a Brazilian context via social indicators research established by Ethos Institute (2013) in their questionnaire for implementation and evaluation of politics and responsibility actions on Brazilian companies. This second model presents a total of 23 indicators.

The classification of likert scale adopted was different from the first part of questionnaire, since the measure of socio-environmental practices follows a differentiate pattern for not being of concordance or influence. In this manner like on the scale used by Zhu and Sarkis (2004), the classification is divide into: (1) not considered, (2) is planning to be considered, (3) it is currently considered (but not reached), (4) it is partially reached, (5) it is reached.

The statistic methods adopted for data collected analysis on this research groups factor analysis exploratory and confirmatory. According to Hair Jr. et al. (2009) the factor analysis is a technique of interdependence that seeks to identify relations between proposed constructs by the study. This technique allows an analysis on these relations establishing correlations between the multiple indicators that are now called 'factors'. The main goal is to group indicators in an under number of dimensions, condensing the information in a way to adjust dimensions to constructs defined conceptually or not.

For this research was used factorial analysis exploratory for data treatment in way to group indicators on correspondent factors and indicate the necessity or not of exclusion of any indicator. On the other hand, confirmatory factor analysis was adopted to evaluate the construction of the pressures models and practices accomplished by the companies researched.

\section{PRESENTATION AND DATA ANALYSIS}

\subsection{General data of the respondents}

The research data collection contemplates small medium, and large companies, being excluded only micro-companies. Table 1 presents data about the companies that responded and the field of activity of each one, as well as their participation related to the total of contacted companies. For this table it is possible to observe the participation of each sector of activity in the transformation industry of the state of Minas Gerais in the sample researched. It is noticeable that the sectors were mostly from the food industry, in which drinks and dairy manufacturers are included with $32 \%$ of participation, as well as food manufacturers; and the chemical industry, in which chemical, pharm chemical and pharmaceutical manufacturers are included with $36.6 \%$ of participation.

Table 1: Participation of transformation industries in the sample

\begin{tabular}{|l|c|c|c|c|}
\hline Classification & Freq. & $\begin{array}{l}\text { Partic i pati on } \\
\text { Sample \% }\end{array}$ & $\begin{array}{l}\text { Total Con- } \\
\text { tacted }\end{array}$ & $\begin{array}{l}\text { Part. Total Con- } \\
\text { tact. \% }\end{array}$ \\
\hline Manufacture of Food Products & 42 & $32,0 \%$ & 149 & $28,19 \%$ \\
Manufacture of Textile Products & 5 & $3,8 \%$ & 12 & $41,67 \%$ \\
Manufacture of Leather and Shoes & 4 & $3,1 \%$ & 54 & $7,41 \%$ \\
Manufacture of Wood Products & 1 & $0,8 \%$ & 2 & $50,00 \%$ \\
Manufacture of Cellulose and Paper & 7 & $5,4 \%$ & 38 & $18,42 \%$ \\
Manufacture of Chemical Products & 48 & $36,6 \%$ & 133 & $36,09 \%$ \\
Basic Metallurgy & 11 & $8,4 \%$ & 158 & $6,96 \%$ \\
Manufacture of Metal Products & 3 & $2,3 \%$ & 141 & $2,13 \%$ \\
Manufacture of Mach. \& Elec. Materials & 2 & $1,5 \%$ & 112 & $1,79 \%$ \\
Manufacture of Furniture & 6 & $4,6 \%$ & 60 & $10,00 \%$ \\
Recycling & 2 & $1,5 \%$ & 6 & $33,33 \%$ \\
\hline Total & 131 & $100 \%$ & 865 & ---- \\
\hline
\end{tabular}


Abdala, E. C., Barbieri, J. C.: Determinants of Sustainable Supply Chain: an Analysis of Mensuration Models of Pressures and Socio-Environmental Practices 117 ISSN: 1984-3046 • Journal of Operations and Supply Chain Management Volume 7 Number 2 p 110 - 123

Not much more than $30 \%$ of respondents occupied positions related to environmental area, being of supervision or management. Approximately 15\% of the participants are responsible for production area or environmental engineering, areas also related to the central topic of the thesis, which establishes relation between operational areas and environment.

\subsection{EXPLORATORY FACTOR ANALYSIS}

Exploratory factor analysis was used as a preliminary evaluation tool. For the purpose of factors definition and justification of the sample, the researched model is presented divide into two: constructs' analysis related to pressures of what constructs' analysis is referred. From the exploratory data analysis can be identified the necessity of exclusion of some indicators, especially after application of reliability tests, using Cronbach's Alpha. The results pointed out to the permanence of a 17 indicators total for Pressures Model and 22 for Practices mode.

\subsection{CONFIRMATORY FACTOR ANALYSIS}

The confirmatory factor analysis was adopted as a step for evaluating the terms of error of the indicators that composes the constructs.This way it seeks the validation and reliability of mensuration models proposed considering data treatment accomplished on exploratory analysis stage. On the process of confirmatory analysis it was achieved the constructs validity by two different methods: the convergent validity and discriminant validity. The convergent validity refers how much the relator indicators to defined constructs on the model converge or share a common variance while discriminating validity refers the level of a certain constructs differentiate from the other model constructs and that the items, individually, represent only one constructs. (HAIR JR. et al. 2009; KLINE, 2011).

\subsubsection{Measurement Model for Pressures}

The original 'Pressures' model was composed by 5 constructs, characterized by Governmental Actions (AG), Suppliers (FOR), Clients (CL) and Organizational Internal Aspects (AIOR) and Operational Internal Aspects (AIOP), beyond 17 indicators. The first mensuration model presents the constructs 'Internal Aspects' divided into two constructs: organizational internal aspects and operational internal aspects, as indicated by statistics calculation of ex- ploratory factor analysis.

The construct Governmental Actions presented fit problems and had to be dropped from the analysis. This does not mean that governmental actions are not aspects that contribute to the adoption of socioenvironmental practices in organizations. But, considering the sample that was studied and de indicators related to measurement of constructs, this one was not validated by the used statistics techniques. In this research the construct 'Governmental Actions' that was built by 5 indicators based on other researches, as mentioned before. One of the indicators treated about the issue of governmental regulation as pressure for adoption of practices. The model adjust was only possible after all constructs exclusion, because adjusts indices obtained significant improvement. We may assume those indices which are not related to regulations and laws, and that were considered as indicators to the research are not sufficient to explain the pressure carried out by the government, and that only regulation should be a strong indication of association with practices.

The Model Reviewed of Pressure has 12 indicators, 3 indicators for each construct, maintaining the original construct of internal aspects divide into two, according to figure 1 :

\section{Figure 1: Model Reviewed of Pressures}

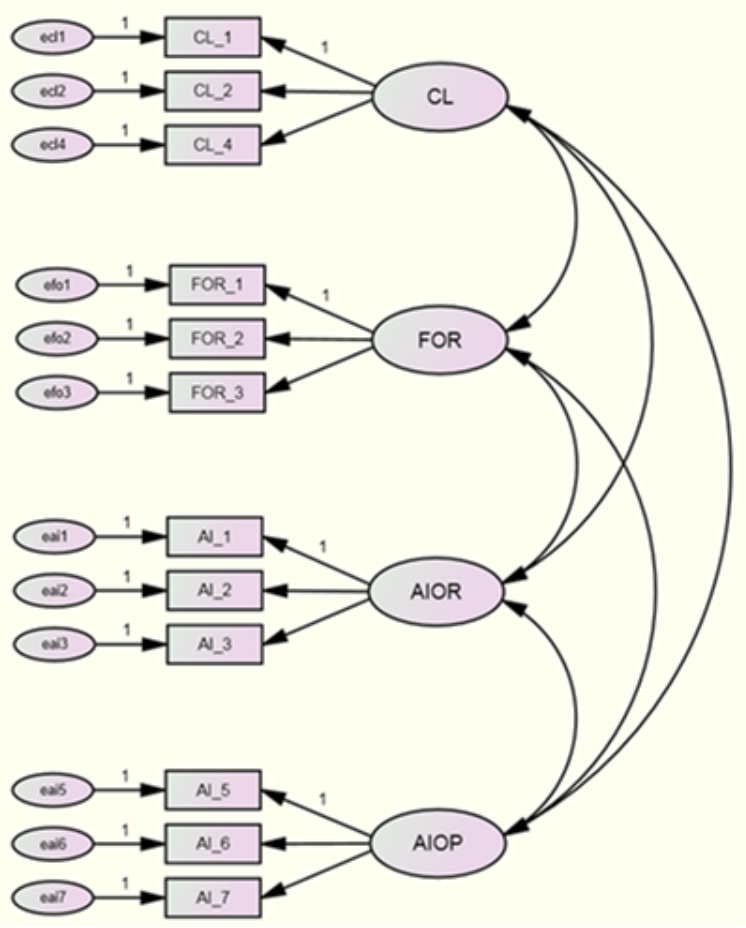


The values found by convergent validity method confirm that the coefficients of composite reliability (CR) or of construct and average variance extracted (AVE) of all constructs of Pressures Model are inside the values of reference. (CC >0,70; AVE >0,50), which validates the model in terms convergent va- lidity. For evaluation of the discriminant validity we used the Fornell and Lacker (1981) method, in which the square of the correlation coefficient between the latent variables is calculated and compared with the average variance extracted (AVE) of each construct. Table 2, as follows, presents the values:

Table 2: Analysis of Discriminant Validity Pressures Model

\begin{tabular}{|l|c|c|c|c|}
\hline Constructs & CL & FOR & AIOR & AIOP \\
\hline CL & 0,735 & --- & --- & --- \\
FOR & 0,498 & 0,643 & --- & --- \\
AIOR & 0,350 & 0,299 & 0,568 & --- \\
AIOP & 0,343 & 0,263 & 0,397 & 0,583 \\
& & & & \\
\hline
\end{tabular}

Source: own elaboration from research data

It can be noted on table 2 that none of the squared construct correlation indices values was greater than the AVE coefficients in relation to each construct (diagonal), which guarantees the discriminant validity of the model. It can therefore be concluded that the defined constructs for this model diverge from each other, proving that the construct is unique and measures situations that other constructs are unable to measure.

\subsubsection{Measurement Model for Practices}

The second model studied was of mensuration of socio-environmental practices. The initial analysis maintained the 5 constructs, which are Environmental Management Activities (AGE), External Environmental Practices (PAE), Development of Environmentally Correct Products (CAPD), and Social Practices (OS), measured by a total of 22 indicators. In the first round of tests about the original mensuration model it was observed that the values of the indices GFI, RMSEA, CFI, and TLI were not inside the parameters considered acceptable to validate the model, indicating fit problems. For this reasons other rounds of tests were done, excluding indicators and inserting covariance between the errors.

The option for the covariance inclusion in mensuration errors that occurred because the indicators (or mensuration items) that presented this covariance between errors presents certain similarity of understanding, in other words, the respondents may have interpreted as similar the questions that represents such indicators. According Hair et al. (2009) this type of action must be adopted with parsimony, and it is not recommended in most of the cases, except if the significant covariance of errors point out that there are a more specific aspect of mensuration that it is not represented by the standard factor loaders. For this respect, Hair et al. (2009) suggest consider Babin e Griffin (1998) research about the cases in that the potential mensuration errors can contaminate the indicators (or items) making the interpretation confuse with other constructs or items that they could be related. The model would be less parsimonious if compared to a congenerous model, but would be adequate in terms of adjust indices. However, even with the covariance between mensuration errors of some indicators, the values of the adjust indices remained out of the reference values.

At a further step, it was decided on the next round for the exclusion of the indicators PAE_1, PAE_7 and PS_3. This way was possible to reach the mensuration model reviewed of the Practices exposed on figure 2. It is notice that was included covariance on errors between the indicators DPAC_3 and DPAC_4; and between PS_4 e PS_5. After the exclusion of the indicator PS_2 and the insertion of covariance the reviewed model more adjusted was reached. 
Figure 2: Review Model of Practices

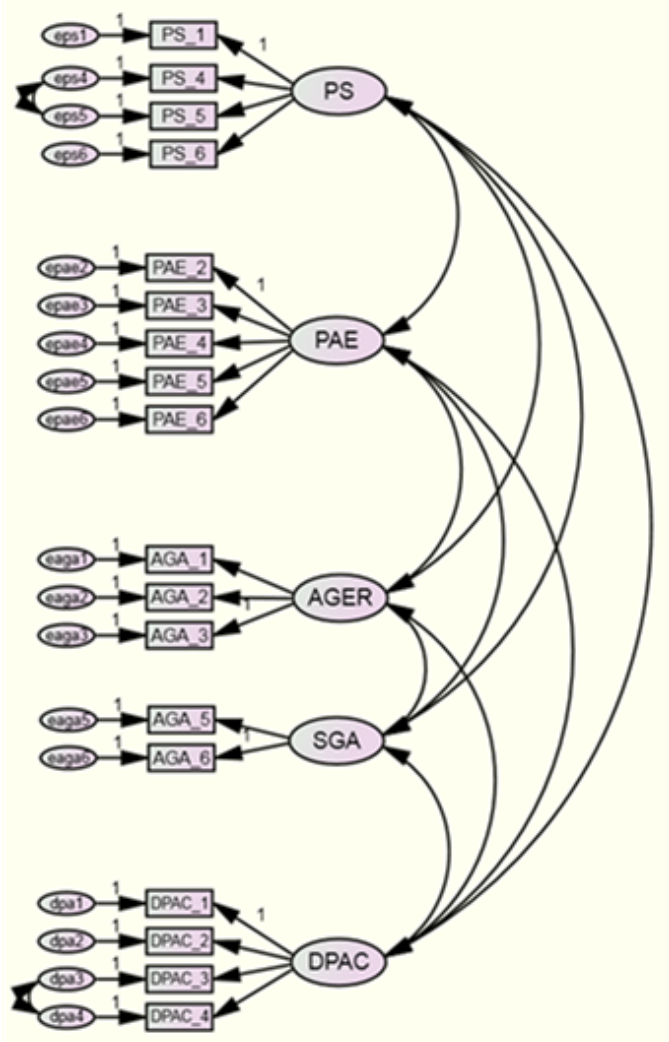

In this reviewed model of Practices Mensuration 4 indicators were excluded (PAE_1, PAE_7 , PS_2, PS_3), resulting in a total of 18 indicators distributed into 5 constructs. After the achievement of calculation, the $\mathrm{CR}$ (compost reliability) confirmed that the coefficients of compost reliability or of constructs and the average variance extracted (AVE) of all constructs of Practice Model are inside the reference values, what makes a valid model in terms of convergent validity.

In the case of discriminant validity it was decided to calculate the discriminant analysis of the relation between this constructs by the difference on values of Chi-squared $\left(\chi^{2}\right)$ between two factors, as suggested by Bagozzi, Yi e Phillips (1991), because the correlations values between the constructs PAE and PS; SGA and PS and between SGA and PAE were superior to AVE, which does not provide discriminant validity by Fornell e Lacker (1981) method. Other studies, like Peng, Schroeder e Shah (2008) adopt two discriminant validation methods to validate the research model proposed, allowing that it may use any of the methods.

Table 3 presents the validity discriminant results for most problematic cases in the measurement model of Practices:

Table 3: Analysis of Discriminant Validity by the method of Bagozzi, Yi and Phillips (1991)

\begin{tabular}{|l|c|c|c|c|}
\hline Correlation & $\begin{array}{c}\text { Chi-squared } \\
\text { Free Model }\end{array}$ & $\begin{array}{c}\text { Chi-squared } \\
\text { Fixed Model }\end{array}$ & $\begin{array}{c}\text { Difference of } \\
\text { Chi-squared }\end{array}$ & p-value \\
\hline Between PAE and OS & 41,13 & 45,713 & 4,583 & 0,03 \\
Between SGA and PS & 2,16 & 2,66 & 0,503 & 0,48 \\
Between SGA and PAE & 29,05 & 32,24 & 3,19 & 0,07 \\
\hline
\end{tabular}

Source: own elaboration

By the analysis of the figures in Table 3 it is possible to notice that there was discriminant validity between PAE and PS because p-value was inferior that 0,05 . Nevertheless, between the constructs SGA and PS and SGA and PAE there was no discriminant validity, or, there are evidences that the constructs are not sufficiently different, at least empirically. As the problem happened between the construct SGA and other two constructs, we opted for the exclusion of the construct SGA from the mensuration model. Additionally the SGA construct had only two indicators, which is not recommended by Hair et al. (2009).
The final measurement model of practices can be considered valid and with an acceptable level of fit, including 4 constructs and 16 indicators.

\section{FINAL REMARKS}

In this study the governmental aspects were not decisive for the determination of the practices. Summarizing, the non-proof of mensuration model of pressures with the inclusion of GA (Governmental Actions) demonstrates a result that diverges from most of the researches already done about the pres- 
sures of adopting socio-environmental actions, that maintains, in terms of results the positive influence of aspects like government, laws or environmental regulation about sustainability in supply chain management (HENRIQUES AND SADORSKY, 1996, ZHU AND SARKIS, 2007; SEURING AND MULLER, 2008b; CLARK, 2012; BERARDI, 2012). Even so, the confirmatory factor analysis made possible the validation of the mensuration model with the permanence of 'Suppliers' constructs and their three indicators, despite of one of them present a factor load inferior that what was expected, according to reference values.

This research intention when includes on mensuration model of pressures the internal factors was based on the arguments demonstrated mainly by Ageron et al. (2011) and Paulraj (2011). The research of Clark (2012) shows that internal aspects like organizational mission and environment worries as well as the ones that most play influence for the adoption of sustainable practices, what in a certain ways is reinforced by the study of this academic research, that was based on an statistic analysis more accurate.

The practices evaluation occurred on social and environmental dimensions, but not directly on economic. Because of that, the research was not realized with the intention of evaluate the three pillars of TBL (triple bottom line) related to the practices, but to direct the questioning for the socials and environmental questions, concomitantly. But, the intention was not specifically evaluate the performance but to this internal objectives of the organizations could be determinants for the realization of socio-environmental practices.

The researches referenced in this study do not define or identify specific indicators to measure social practices. The social indicators established in the research instrument (survey) were adapted to Brazilian context, considering items evaluated by Institute Ethos. One of the justifications for this adaptation is the fact that multiples of conceptual requirements considered in this research come from foreign researches that approach a different context from what can be found in Brazil.

The conclusion of the study suggests that the creation of new products and its own environmental management of the company are related to the internal environmental initiatives, and thus, this should be continuously stimulated. The realization of proper Social environmental practices depends on the frequency of the stimulus, preferably with higher level of intensity in Brazilian companies. Even though there are internal stimulus and external pressures, specific practices are not considered with the relevance they should be to compose a sustainable supply chain. In this sense, it is necessary that the organizations change their habits and routines in a way to be translated into sustainable actions in the three sustainability dimensions: economic, environmental e social.

\section{REFERENCES}

AGERON, et al. Sustainable supply management: an empirical study. International Journal of Production Economics. 2011.

ANGELL, L. C.; KLASSEN, R. D. Integrating environmental issues into the mainstream: an agenda for research in operations management. Journal of Operations Management. v. 17, p. 575-598, 1999.

BABIN, B. J.; GRIFFIN, M. The nature of satisfaction: an updated examination and analysis. Journal of Business Research. v. 41. p. 127-136. 1998.

BAGOZZI, R. P.; YI, Y.; PHILLIPS, L. W. Assessing construct validity in organizational research. Administrative Science Quarterly.v. 36, n. 3, p. 421-458. Sep. 1991.

BANSAL, P. Evolving sustainability: a longitudinal study of corporate sustainable development. Strategic Management Journal. v. 26, p. 197-218. 2005.

BERARDI, P. C. Fatores indutores à evolução da gestão ambiental na indústria : uma abordagem pela Teoria Institucional. 2012. 228 f. Tese de Doutorado. (Doutorado em Administração). Escola de Administração de Empresas de São Paulo - Fundação Getúlio Vargas. São Paulo. 2012.

CARTER, C. R.; JENNINGS, M. M. The role of purchase in corporate social responsibility: a structural equation analysis. Journal of Business Logistics. v. 25. n. 1, p. 145-186. 2004.

CARTER, C. R.; ROGERS, D. S. A framework of sustainable supply chain management: moving toward new theory. International Journal of Physical Distribution \& Logistics Management. v. 38, n. 5, p. 360-387, 2008.

CLARK, A. L. Barriers and drivers to sustainability for small to medium sized business in the value added wood sector. Thesis submitted for the Degree of Master of Science. Dissertação de Mestrado. The University of British Columbia. Vancouver. 2012.

CRUZ, L. B.; PEDROSO, E.; MARTINET, A. Estratégias de desenvolvimento sustentável em grupos multinacionais: o estudo de dois casos franceses no setor de varejo. Revista de Gestão Social e Ambiental. v. 1, n. 3, p. 58-78. Set. /Dec. 2007.

DELMAS, M.; TOFFEL, M. W. Stakeholders and environmental management practices: an institutional framework. Business Strategy and the Environment. v. 13, p. 209-222. 2004.

ELKINGTON, J. Canibais com garfo e faca. São Paulo: Makron Books, 2001. 
ELTAYEB, T. K.; ZAILANI, S. Going green through green supply chain initiatives towards environmental sustainability. Operations and Supply Chain Management. v. 2, n. 2, p. 93-110. May. 2009.

FORNELL, C.; LARCKER, D. F. Evaluating structural equation models with unobservable variables and measurement error: algebra and statistics. Journal of Marketing. v.18, n. 1, p. 3959, Feb. 1981.

GLADWIN, T. N. KENNELLY, J. J.; KRAUSE, T. S. Shifting paradigms for sustainable development: implications for management theory and research. The Academy of Management Review. v. 20, n. 4, p. 874-907. Oct., 1995.

GLAVIC, P.; LUKMAN, R. Review of sustainability terms and their definitions. Journal of Cleaner Production. v. 15, p. 1875-1885. 2007.

GOLD, S.; SEURING, S.; BESKE, P. The constructs of sustainable supply chain management - a content analysis based on published case studies. Progress in Industrial Ecology - An International Journal. v. 7, n. 2, p. 114-137. 2010.

HAIR Jr.; J. F. et al. Fundamentos de métodos de pesquisa em administração. Porto Alegre: Bookman, 2005.

HAIR Jr.; J. F. et al. Análise multivariada de dados. Porto Alegre: Bookman, 2009.

HALL, J. Environmental supply chain dynamics. Journal of Cleaner Production. v. 7, p. 455-471. 2000.

HANDFIELD, R.B. et al. Green value chain practices in the furniture industry. Journal of Operations Management. v. 15, p. 293-315. 1997.

HENRIQUES, I.; SADORSKY, P. The determinants of an environmentally responsive firm: an empirical approach. Journal of Environmental Economics and Management. v. 30. p. 381-395. 1996.

HOLLOS, D.; BLOME, C.; FOERSTL, K. Does sustainable supplier co-operation affect performance? Examining implications for the triple bottom line. International Journal of Production Research. 2011

KLEINDORFER, P. R.; SINGHAL, K.; WASSENHOVE, L. N. V. Sustainable Operations Management. Production and Operations Management. v. 14, n. 4, p. 482-492. Winter, 2005.

KLINE, Rex B. Principles and Practice of Structural Equation Modeling. 3. ed. New York: The Guilford Press, 2011.

KOPLIN, J.; SEURING, S.; MESTERHARM, M. Incorporating sustainability into supply management in the automotive industry - the case of Volkswagen AG. Journal of Cleaner Production. v. 15, p. 1053-1062. 2007.

KRAUSE, D. R.; VACHON, S.; KLASSEN, R. D. Special topic forum on sustainable supply chain management: introduction and reflections on the role of purchasing management. Journal of Supply Chain Management. v. 45, n. 4, p. 18-25. October 2009.

LINTON, J. D.; KLASSEN, R.; JAYARAMAN, V. Sustainable supply chains: an introduction. Journal of Operations Management. v. 25, p. 1075-1082, 2007.
MANN, H. et al. Drivers of sustainable supply chain management. The IUP Journal of Operations Management. v. 9, n.4, p. 52-63. 2010

MINATTI, C.; ALBERTON, A.; MARINHO, S. V. Direções e construtos do green supply chain management. Anais. XIV Simpósio de Administração da Produção, Logística e Operações Internacionais. Simpoi 2011. São Paulo, 2011.

NEUTZLING, D. M.; LIBERA, A. A. D.; PEDROZO, E. A. Gestão da sustentabilidade na cadeia de suprimentos do frango de corte em Mato Grosso. Anais. XIII Encontro Nacional sobre Gestão Empresarial e Meio Ambiente. Engema. 2011. São Paulo, 2011.

NORDHAUS, W. D. Reflections on the concept of sustainable economic growth. Cowles Foundation for Research in Economics at Yale University. 1998.

O'BRIEN, C. Sustainable production - a new paradigm for a new millennium. International Journal of Production Economics. v. 60-61, p. 1-7. 1999.

PAGELL, M.; WU, Z. Building a more complete theory of sustainable supply chain management using case studies of 10 exemplars. Journal of Supply Chain Management. v. 45, n. 2, p. 37-56. April 2009.

PAULRAJ, A. Understanding the relationships between internal resources and capabilities, sustainable supply management and organizational sustainability. Journal of Supply Chain Management. v. 47, n. 1, p. 19-37. 2011

PENG, D. X; SCHROEDER, R. G.; SHAH, R. Linking routines to operations capabilities: a new perspective. Journal of Operations Management. v. 26. p. 730-748. 2008.

PUlLMAN, M. E; MALONI, M. J; CARTER, C. R. 2009. Food for thought: social versus environmental sustainability practices and performance outcomes. Journal of Supply Chain Management. v. 45, n. 4, p. 38-54. Out. 2009.

PORTER, M.; VAN DER LINDE, C. Green and competitive: ending the stalemate. Harvard Business Review. v. 73, n. 5, p. 120-134. September-October, 1995.

PREUSS, L. In dirty chains? Purchasing and greener manufacturing. Journal of Business Ethics. v. 34. p. 345-359. 2001.

ROBERTS, S. Supply chain specific? Understanding the patchy success of ethical sourcing initiatives. Journal of Business Ethics. v. 44, p. 159-170. 2003.

RON, A. J. Sustainable production: the ultimate result of a continuous improvement. . International Journal of Production Economics. v. 56-57, p. 99-110. 1998.

ROUTROY, S. Antecedents and drivers for green supply chain management implementation in manufacturing environment. The Icfai Journal of Supply Chain Management. v. 6, n. 1, p. 20-35. 2009

SARKIS, J. Manufacturing's role in corporate environmental sustainability: concerns for the millennium. International Journal of Operations and Productions Management. v. 21, n. 5/6, p. 666-286. 2001.

SEURING, S.; MULLER, M. Integrated chain management in Germany: identifying schools of thought based on a litera- 
ture review. Journal of Cleaner Production. v. 15, p. 699710. 2007.

SEURING, S.; MULLER, M. Core issues in sustainable supply chain management: a delphy study. Business Strategy and The Environment. v. 17, n. 8, p. 455-466. 2008a

SEURING, S. MULLER, M. From a literature review to a conceptual framework for sustainable supply chain management. Journal of Cleaner Production. v. 16, p. 1699-1710, 2008b

SHARMA, S.; HENRIQUES, I. Stakeholder influences on sustainability practices in the Canadian forest products industry. Strategic Management Journal. v. 26, n. 2, p. 159-180. Feb. 2005.

SRIVASTAVA, S. K. Green supply chain management: a state-ofart literature review. International Journal of Management Reviews. v. 9, n. 1, p. 53-80. 2007.

TATE, W. L.; ELLRAM, L. M.; KIRCHOFF, J. F. Corporate social responsibility reports: at thematic analysis related to supply chain management. Journal of Supply Chain Management. v. 46, n. 1, p. 19-44, 2010.

VACHON, S.; KLASSEN, R. D. Extending green practices across the supply chain: the impact of upstream and downstream integration. International Journal of Operations and Pro- duction Management. v. 26, n. 7, p. 795-821. 2006.

VACHON, S.; MAO, Z. Linking supply chain strength to sustainable development: a country-level analysis. Journal of Cleaner Production. v. 16, p. 1552-1560. 2008.

WELFORD, R.; FROST, S. Corporate social responsibility in Asian supply chains. Corporate Social Responsibility and Environmental Management. v. 13, p. 166-176. 2006.

ZSIDISIN, G. A.; SIFERD, S. P. Environmental purchasing: a framework for theory development. European Journal of Purchasing \& Supply Management. v. 7, p. 61-73. 2001.

ZHU, Q.; SARKIS, J. Relationships between operational practices and performance among early adopters of green supply chain management practices in Chinese manufacturing enterprises. Journal of Operations Management. v. 22, p. 265-289, 2004.

ZHU, Q.; SARKIS, J.; GENG, Y. Green supply chain management in China: pressures, practices and performance. International Journal of Operations and Production Management. v. 25, n. 5/6, p. 449-468. 2005.

ZHU, Q; SARKIS, J. The moderating effects of institutional pressures on emergent green supply chain practices and performance. International Journal of Production Research. v. 45 n. 18-19, p. 4333-4355. 2007. 


\section{AUTOHR'S BIOGRAPHY:}

Etienne Cardoso Abdala: Professor of Business at Federal University of Uberlandia, PhD in Business Administration at FGV/EAESP, Master in Production Engineering at EESC/USP. Researcher in social and environmental aspects and sustainability.

José Carlos Barbieri: Professor at Operations and Production Department - POI - FGV/EAESP. PhD in Business Administration at FGV/EAESP. Professor and Researcher of sustainability, environmental and social aspects of business administration. 